$\begin{array}{r}\text { HשMAdNIS } \\ \text { HUMANIS } \\ \text { Journal of Arts and Humanities } \\ \text { p-ISSN: 2528-5076, e-ISSN: 2302-920X } \\ \text { Terakreditasi Sinta-4, SK No: 23/E/KPT/2019 } \\ \text { Vol 26.1 Februari 2022: 56-67 } \\ \hline\end{array}$

\title{
Penerjemahan Kanyouku dalam Novel Shikisai wo Motanai Tazaki Tsukuru to Kare no Junrei no Toshi Karya Haruki Murakami
}

\author{
Febri Nur Dwiyanti, Hermandra, Intan Suri \\ Universitas Riau, Pekanbaru, Provinsi Riau \\ Email korespondensi: febrinurdwiyanti@gmail.com, hermandra@,lecturer.unri.ac.id, \\ intan.suri@,lecturer.unri.ac.id
}

\begin{tabular}{|c|c|}
\hline Info Artikel & Abstract \\
\hline \multirow[t]{2}{*}{$\begin{array}{l}\text { Keywords: } \\
\text { kanyouku translation, strategy, } \\
\text { colorless tsukuru tazaki }\end{array}$} & $\begin{array}{l}\text { Idioms in Japanese are called kanyouku. This study aims to } \\
\text { describe the kanyouku translation strategies and procedures } \\
\text { contained in the novel. The theory used in this study are the } \\
\text { theory of idiom translation strategy according to Baker (1992) } \\
\text { and the theory of translation procedures according to Vinay \& } \\
\text { Darbelnet in Venuti (2000). This research is a qualitative } \\
\text { descriptive research. The data in this study are the kanyouku of } \\
\text { the upper limbs contained in the novel Shikisai wo Motanai } \\
\text { Tazaki Tsukuru to Kare no Junrei no Toshi (2013) by Haruki } \\
\text { Murakami and its translation in Indonesian "Tsukuru Tazaki } \\
\text { Without Color and the Year of His Pilgrimage" (2018) which is } \\
\text { translated by Ribeka Ota. From the result of the analysis of } 35 \\
\text { kanyouku it was found that the kanyouku translation strategy } \\
\text { used by the translator was a strategy using an idiom of similar } \\
\text { meaning and form and a paraphrasing strategy. While the } \\
\text { translation procedures used are literal translation, } \\
\text { transposition and equivalence. }\end{array}$ \\
\hline & Abstrak \\
\hline $\begin{array}{l}\text { Kata kunci: } \\
\text { penerjemahan kanyouku, } \\
\text { strategi, tsukuru tazaki tanpa } \\
\text { warna }\end{array}$ & $\begin{array}{l}\text { Idiom dalam bahasa Jepang disebut kanyouku. Penelitian ini } \\
\text { bertujuan untuk mendeskripsikan strategi dan prosedur } \\
\text { penerjemahan kanyouku yang terdapat dalam novel. Teori yang } \\
\text { digunakan dalam penelitian ini adalah teori strategi } \\
\text { penerjemahan idiom menurut Baker (1992) dan teori prosedur } \\
\text { penerjemahan menurut Vinay \& Darbelnet dalam Venuti }\end{array}$ \\
\hline $\begin{array}{l}\text { Corresponding Author: } \\
\text { Febri Nur Dwiyanti } \\
\text { Email : } \\
\text { febrinurdwiyanti@gmail.com }\end{array}$ & $\begin{array}{l}\text { (2000). Penelitian ini adalah penelitian deskriptif kualitatif. } \\
\text { Data pada penelitian ini adalah kanyouku anggota tubuh } \\
\text { bagian atas yang terdapat dalam novel Shikisai wo Motanai } \\
\text { Tazaki Tsukuru to Kare no Junrei no Toshi (2013) karya } \\
\text { Haruki Murakami dan terjemahannya dalam bahasa Indonesia } \\
\text { "Tsukuru Tazaki Tanpa Warna dan Tahun Ziarahnya" (2018) }\end{array}$ \\
\hline $\begin{array}{l}\text { DOI: } \\
\text { https://doi.org/10.24843/JH.20 } \\
\underline{22 . v 26 . i 01 . p 07}\end{array}$ & $\begin{array}{l}\text { yang diterjemahkan oleh Ribeka Ota. Dari hasil analisis } \\
\text { terhadap } 35 \text { kanyouku ditemukan bahwa strategi penerjemahan } \\
\text { kanyouku yang digunakan oleh penerjemah adalah strategi } \\
\text { menggunakan idiom dengan makna dan bentuk yang mirip dan } \\
\text { strategi parafrasa. Prosedur penerjemahan yang digunakan } \\
\text { adalah terjemahan harfiah, transposisi dan kesepadanan. }\end{array}$ \\
\hline
\end{tabular}




\section{PENDAHULUAN}

Penerjemahan dan bahasa asing adalah dua hal yang saling berkaitan erat. Dalam proses penerjemahan lisan maupun tulisan diperlukan 2 bahasa yang berbeda, masing-masing berperan sebagai bahasa sumber (BSu) dan bahasa sasaran (BSa). Menurut Machali (2000:5) penerjemahan adalah upaya mengganti teks bahasa sumber (TSu) ke teks yang sepadan dalam bahasa sasaran (TSa) dan yang diterjemahkan adalah makna sebagaimana yang dimaksud pengarang.

Dalam proses menerjemahkan teks $\mathrm{BSu}$ ke dalam teks BSa diperlukan kesepadanan. Permasalahan kesepadanan diantaranya adalah adanya muatan budaya atau unsur kebahasaan dalam $\mathrm{BSu}$ yang berbeda atau tidak dimiliki oleh BSa. Oleh karena itu, perbedaan sistem dan struktur antara $\mathrm{BSu}$ dan $\mathrm{BSa}$ menjadi kendala utama dalam penerjemahan (Hoed, 2006:24). Salah satu contoh masalah khusus yang sering dijumpai dalam penerjemahan adalah penerjemahan idiom (Nida dan Taber, 1969:106).

Idiom dalam bahasa Jepang disebut kanyouku. Muneo (1992) mendefinisikan kanyouku sebagai gabungan dari dua kata atau lebih yang maknanya mewakili satu makna secara keseluruhan dan digunakan sebagai padanan dari satu kata dalam sebuah kalimat. Kanyouku biasanya digunakan untuk memperhalus dan mempersingkat ucapan.

Kanyouku sering digunakan oleh para native bahasa Jepang dalam berkomunikasi baik secara lisan maupun tulisan. Selain itu kanyouku juga sering muncul dalam soal Japanese Language Proficiency Test (JLPT), komik 'manga', novel, lirik lagu dan karya sastra lainnya.

Kanyouku tidak bisa diartikan secara leksikal saja karena mengandung makna idiomatikal. Kesulitan dalam memahami makna idiomatikal biasanya muncul ketika melakukan penerjemahan baik secara lisan maupun tulisan.
Penerjemahan memiliki kaitan yang sangat erat dengan kebudayaan yang melatarbelakangi $\mathrm{BSu}$ dan BSa (Dadi, 2018). Selain harus memiliki pemahaman terhadap budaya negara $\mathrm{BSu}$ dan $\mathrm{BSa}$, penerjemah juga harus memahami strategi dan prosedur penerjemahan idiom agar makna dan pesan dari teks $\mathrm{BSu}$ dapat disampaikan dengan baik dalam teks BSa. Sebelum menganalisis strategi dan prosedur penerjemahan kanyouku, kanyouku perlu diklasifikasikan berdasarkan struktur pembentuk (Miharu, 2002) dan maknanya (Muneo,1992) terlebih dahulu.

Baker (1992) dalam bukunya yang berjudul In Other Words : A Coursebook on Translation menyebutkan ada 4 strategi yang dapat digunakan untuk menerjemahkan idiom dari BSu ke dalam $\mathrm{BSa}$, yaitu menggunakan idiom yang makna dan bentuknya mirip, menggunakan idiom yang maknanya mirip namun bentuknya berbeda, penerjemahan dengan parafrasa dan tidak diterjemahkan atau penghilangan.

Selain strategi penerjemahan yang digunakan sebagai langkah awal penerjemahan idiom, diperlukan prosedur penerjemahan untuk mengkaji lebih dalam mengenai penerjemahan idiom dari BSu ke dalam BSa. Menurut Vinay dan Darbelnet (dalam Venuti, 2000) ada 7 prosedur penerjemahan yang dapat digunakan oleh penerjemah. Prosedur penerjemahan tersebut adalah Borrowing 'Peminjaman', Caique, Literal translation 'Terjemahan harfiah', Transposition 'Pergeseran bentuk', Modulation 'Pergeseran makna', Equivalence 'Kesepadanan', dan Adaptation 'Adaptasi'.

Dalam penelitian ini akan digunakan sumber analisis berupa novel. Di dalam novel tergambar tindakan, pemikiran dan penggunaan idiom yang relevan dengan kehidupan sehari-hari, sehingga cocok menjadi sumber data dalam penelitian ini. 
Salah satu novel best-seller karya penulis ternama Jepang Haruki Murakami adalah Shikisai wo Motanai Tazaki Tsukuru to Kare no Junrei no Toshi atau dalam bahasa Inggris berjudul Colorless Tsukuru Tazaki and His Years of Pilgrimage. Novel ini merupakan karya ke-13 dari Haruki Murakami yang diterbitkan oleh Bungeishunju pada 12 April 2013 di Jepang. Dalam kurun waktu 1 bulan sejak perilisannya, novel yang terdiri dari 370 halaman ini berhasil terjual sebanyak 1 juta eksemplar. Novel ini kemudian diterjemahkan oleh Philip Gabriel ke dalam bahasa Inggris (2014) dan diterjemahkan ke dalam bahasa Indonesia oleh Ribeka Ota (2018).

Ribeka Ota adalah seorang penerjemah berdarah Jepang yang sudah lama tinggal di Indonesia dan telah menerjemahkan banyak novel bahasa Jepang ke dalam bahasa Indonesia. Novel terjemahannya antara lain seri IQ84 (2013) dan Kronik Burung Pegas (2019) karya Haruki Murakami, Oda Nobunaga (2013 \& 2014) karya Sohachi Yamaoka, Taira no Masakodo (2012) dan Naruto Hicho (2014) karya Yoshikawa Eiji dan penulis lainnya, termasuk menerjemahkan Cantik Itu Luka karya Eka Kurniawan ke dalam bahasa Jepang (2006). Proyek terbarunya adalah menerjemahkan 世界から猫が消えたな

\section{5 'Jika Kucing Lenyap dari Dunia'}

karya Genki Kawamura (2020) ke dalam bahasa Indonesia.

Dalam penelitian ini novel Shikisai wo Motanai Tazaki Tsukuru to Kare no Junrei no Toshi (2013) selanjutnya disingkat menjadi SMTTKJT karya Haruki Murakami akan berperan sebagai teks BSu. Novel terjemahannya dalam bahasa Indonesia yang berjudul "Tsukuru Tazaki Tanpa Warna dan Tahun Ziarahnya" (2018) selanjutnya disingkat TTTWTZ dan diterjemahkan oleh Ribeka Ota akan berperan sebagai teks BSa.

$$
\text { Novel SMTTKJT }
$$
menceritakan tentang seorang pemuda bernama Tsukuru Tazaki yang memiliki 4 orang sahabat karib di SMA. Suatu hari Aka, Ao, Shiro dan Kuro mengabarkan bahwa mereka tidak mau lagi bertemu dengannya. Sejak saat itu Tsukuru mengalami depresi dan sempat berpikiran untuk mengakhiri hidupnya. Kemudian ia bertemu Sara yang menyadarkannya bahwa kini sudah waktunya untuk mencari tahu apa yang sebenarnya terjadi.

Dalam bahasa Jepang, kanyouku lahir dari pengalaman hidup masyarakat pemakainya, sehingga dalam kanyouku banyak mengandung unsur alam, hewan, tumbuhan dan anggota tubuh. Kanyouku yang paling banyak dijumpai dalam masyarakat Jepang adalah kanyouku yang berhubungan dengan anggota tubuh (Widiyani, 2016). Anggota tubuh merupakan bagian dari tubuh yang mempunyai peran penting, selain itu anggota tubuh juga dapat menggambarkan berbagai macam ungkapan (Andriani, 2019).

Dalam novel ini ditemukan kanyouku bahasa Jepang yang berhubungan dengan perasaan dan anggota tubuh. Kanyouku yang berhubungan dengan anggota tubuh bagian atas merupakan kanyouku yang sering muncul dan paling banyak jumlahnya di antara anggota tubuh lainnya, sehingga kanyouku yang diteliti dalam penelitian ini akan difokuskan pada kanyouku tubuh bagian atas yaitu 頭 'kepala', 顔 'wajah', 目 'mata', 鼻 'hidung', 耳 'telinga', 口 'mulut' dan 首 'leher'.

$$
\text { Contoh kanyouku yang }
$$

berhubungan dengan anggota tubuh 頭 atama 'kepala' yang ditemukan dalam novel SMTTKJT : 
アカも確かに頭が切れたが、彼の頭

の良さはどちらかといえば実際的で

あり、場合によって功利的な側面を

持ち合わせていた。

$$
\text { (SMTTKJT, 2013:114) }
$$

Aka juga cerdas sekali, namun kecerdasan Aka lebih tertuju kearah kepraktisan dan kadang bisa dikatakan punya sisi yang mengutamakan manfaat.

(Ota, 2018:107)

Kanyouku 頭が切れる 'atama ga kireru' secara leksikal bermakna 'kepala terputus', sedangkan secara idiomatikal berarti 'berpikir cepat, cepat bertindak' (Garrison, 2006:3). Dalam novel terjemahannya, kanyouku atama ga kireru mendapat padanan 'cerdas'. Hubungan makna leksikal dan makna idiomatikal kanyouku dapat dianalisis menggunakan semantik kognitif. Adapun perubahan bentuk dari kanyouku atama ga kireru menjadi 'cerdas' dalam BSa dapat dianalisis menggunakan teori strategi dan prosedur penerjemahan kanyouku.

Keunikan kanyouku serta sulitnya menerjemahkan kanyouku, banyaknya bentuk dan jenis makna kanyouku menjadikan penelitian mengenai penerjemahan kanyouku dalam novel menarik untuk diteliti.

Berdasarkan latar belakang di atas, maka tujuan dari penelitian ini adalah untuk mendeskripsikan bagaimana strategi dan prosedur penerjemahan kanyouku yang digunakan oleh penerjemah dalam novel SMTTKJT (2013) ke dalam novel terjemahannya TTTWTZ (2018).

\section{METODE DAN TEORI}

Penelitian ini adalah penelitian deskriptif kualitatif, yaitu penelitian yang semata-mata hanya berdasarkan fakta yang ada atau fenomena yang memang secara empiris hidup pada penutur-penuturnya, sehingga yang dihasilkan atau dicatat berupa data yang apa adanya (Sudaryanto, 2015:15).

Data yang digunakan pada penelitian ini adalah kanyouku anggota tubuh bagian atas, yaitu 頭 'kepala', 顔 'wajah', 目 'mata', 鼻 'hidung'，耳 'telinga',

'mulut' dan 首 'leher'. Sumber data dalam penelitian ini adalah novel Shikisai wo Motanai Tazaki Tsukuru to Kare no Junrei no Toshi (2013) karya Haruki Murakami dan terjemahannya dalam bahasa Indonesia "Tsukuru Tazaki Tanpa Warna dan Tahun Ziarahnya" (2018) yang diterjemahkan oleh Ribeka Ota.

Metode pengumpulan data yang digunakan adalah metode baca simak dan teknik catat. Teknik analisis data yang digunakan dalam penelitian ini adalah metode padan intralingual dan ekstralingual dengan teknik hubung banding menyamakan dan membedakan.

\section{Klasifikasi Kanyouku Berdasarkan Struktur Pembentuk}

Untuk memudahkan analisis strategi dan prosedur penerjemahan kanyouku, kanyouku perlu diklasifikasikan berdasarkan struktur pembentuk terlebih dahulu.

Miharu (2002:124) membagi kanyouku berdasarkan struktur pembentuknya menjadi 3 , yaitu:

1. Idiom verba (Doushi kanyouku)

2. Idiom adjektiva (Keiyoushi kanyouku)

3. Idiom nomina (Meishi kanyouku) 


\section{Klasifikasi Kanyouku Berdasarkan Makna}

Klasifikasi idiom berdasarkan makna menurut Muneo (1992) dibagi menjadi 5, yaitu :

1) Kankaku, kanjou wo arawasu kanyouku yaitu kanyouku yang menunjukkan indera, perasaan dan emosi, meliputi perasaan senang, sedih, malu, khawatir.

2) Karada, seikaku, taido wo arawasu kanyouku merupakan kanyouku yang menunjukkan tubuh, sifat dan tingkah laku, contohnya sifat percaya diri, sopan, waspada, kerjasama.

3) Koui, dousa, koudo wo arawasu merupakan kanyouku yang menunjukkan kelakuan, gerak dan tindakan.

4) Joutai, teido, kachi wo arawasu kanyouku merupakan kanyouku yang menunjukkan kondisi, tingkatan, nilai atau harga.

5) Shakai, seikatsu, bunka wo arawasu merupakan kanyouku yang menunjukkan kehidupan bermasyarakat, kebudayaan dan kehidupan.

\section{Hubungan Perluasan Makna Kanyouku}

Menurut Sutedi (2011:127) semantik (imiron) merupakan salah satu cabang linguistik (gengogaku) yang mengkaji tentang makna. Objek kajian semantik antara lain makna kata (go no imi), relasi makna antar satu kata dengan kata yang lain (go no imi kankei), makna frasa ( $k u$ no imi) dan makna kalimat (bun no imi). Makna frasa dalam idiom (kanyouku no ku no imi) merupakan bagian dari kajian semantik.

Semantik kognitif digunakan untuk menghubungkan makna leksikal idiom dengan makna idiomatikalnya yang berhubungan dengan kognisi manusia.

Menurut para ahli linguistik, perluasan makna pada idiom dapat diwakili dengan 3 macam gaya bahasa, yaitu metafora, metonimi dan sinekdoke. Momiyama dalam Sutedi (2011:209) menjelaskan mengenai batasan tentang ketiga gaya bahasa tersebut sebagai berikut :

1. Metafora

Merupakan gaya bahasa yang digunakan untuk mengumpamakan sesuatu hal (misalnya A) dengan hal lain (misalnya B) atas dasar kemiripan atau kesamaan. Selain itu dalam metafora dapat ditafsirkan bahwa A merupakan ranah sasaran (target domain) sedangkan B merupakan ranah sumber (source domain).

2. Metonimi

Merupakan gaya bahasa yang digunakan untuk mengumpamakan suatu hal (misalnya A) dengan hal lain (misalnya B) karena asas kedekatan atau keterkaitan baik secara ruang maupun waktu.

3. Sinekdoke

Merupakan gaya yang digunakan untuk mengumpamakan sesuatu hal yang umum (A) dengan hal yang lebih khusus (B), atau sebaliknya hal yang khusus (B) diumpamakan dengan hal yang umum (A).

\section{Strategi Penerjemahan Kanyouku}

Strategi penerjemahan idiom adalah langkah awal yang dilakukan dalam proses penerjemahan idiom. Menurut Baker (1992:71-78), strategi-strategi yang dapat digunakan penerjemah dalam menerjemahkan idiom dari BSu ke dalam BSa ada 4, yaitu sebagai berikut:

1. Using an idiom of similar meaning and form (menggunakan idiom dengan makna dan bentuk yang mirip atau hampir sama)

2. Using an idiom of similar meaning but dissimilar form (menggunakan idiom yang maknanya hampir sama tapi berbeda bentuk)

3. Translation by paraphrase (Penerjemahan dengan Parafrasa) 


\section{Translation by omission (Penerjemahan dengan penghilangan/tidak diterjemahkan)}

\section{Prosedur Penerjemahan Kanyouku}

Prosedur merupakan perbuatan atau cara kerja dalam segala tindakan dan atau proses. Prosedur penerjemahan berlaku untuk kalimat dan satuan-satuan bahasa yang lebih kecil seperti klausa, frasa, kata dan sebagainya. Prosedur penerjemahan idiom merupakan lanjutan dari strategi penerjemahan idiom karena strategi penerjemahan yang disampaikan Baker (1992) hanya berperan sebagai langkah awal dalam menerjemahkan sebuah idiom, atau cara yang bisa dipilih secara garis besar dalam menerjemahkan idiom.

Menurut Vinay dan Darbelnet (dalam Venuti, 2000) ada 7 prosedur penerjemahan yang dapat digunakan oleh penerjemah. Prosedur penerjemahan tersebut adalah Borrowing 'Peminjaman', Caique, Literal translation 'Terjemahan harfiah', Transposition 'Pergeseran bentuk', Modulation 'Pergeseran makna', Equivalence 'Kesepadanan', dan Adaptation 'Adaptasi'.

\section{HASIL DAN PEMBAHASAN}

\section{Data 1}

\section{頭が切れる 'Atama ga kireru'}

Kepala/P/Tajam, putus, memotong

$\mathrm{TSu}$ : アカも確かに頭が切れたが、彼 の頭の良さはどちらかといえ ば実際的であり、場合によつ て功利的な側面を持ち合わせ ていた。

Aka mo tashikani atama ga kireta ga, kare no atama no yosa wa dochira ka to ieba jissaiteki de ari, baai ni yotte kouriteki na sokumen wo machiawaseteita.

(Murakami, 2013:114)
Tsa : Aka juga cerdas sekali, namun kecerdasan Aka lebih tertuju kearah kepraktisan dan kadang bisa dikatakan punya sisi yang mengutamakan manfaat.

(Ota, 2018:107)

Pada data (1) bentuk kamus dari kanyouku 頭が切れた 'atama ga kireta' adalah 頭が切れる 'atama ga kireru'.

Kanyouku ini terbentuk dari gabungan antara nomina ditambah verba, yaitu nomina 頭 'atama', partikel が ' $g a$ ' dan verba intransitif 切れる 'kireru'. Berdasarkan struktur pembentuknya, data (1) kanyouku atama ga kireru termasuk ke dalam idiom verba atau doushi kanyouku.

Nomina atama berarti 'kepala, otak, pikiran' (Matsuura, 2005:39). Verba kireru bermakna 'tajam, putus, terputus, habis, punah, tandas, lewat' (Matsuura, 2005:500). Makna leksikal dari kanyouku pada data (1) adalah 'kepala terputus' dan makna idiomatikalnya adalah 'berpikir cepat, cepat bertindak' (Garrison, 2006:3). Makna idiomatikal atama ga kireru menurut proverbencyclopedia.com adalah 'mampu memutar otak dengan cepat dan memiliki kemampuan untuk menangani suatu hal dengan cepat' sedangkan dalam kamus Matsuura (2005:500) kanyouku atama ga kireru berarti 'pikiran tajam'.

Makna leksikal dan makna idiomatikal kanyouku atama ga kireru mengalami perluasan makna secara metafora dan metonimi (Septiyani, 2018:6).

Hubungan kedekatan antara 'kepala' dan 'otak' atau 'kemampuan berpikir' menunjukkan hubungan perluasan makna secara metonimi bagian dan keseluruhan. Adanya unsur kesamaan atau kemiripan antara 'alat pemotong yang tajam' dan 'memiliki fungsi yang baik' menunjukkan perluasan makna 
secara metafora. Verba kireru atau 'alat pemotong' diibaratkan sebagai ranah sumber dan 'memiliki fungsi yang baik, tajam' merupakan ranah sasaran. Jadi makna leksikal 'kepala terputus' berkembang menjadi 'pikiran yang tajam' atau 'cerdas'. Oleh sebab itu kanyouku atama ga kireru dapat diartikan sebagai 'cerdas, cepat bertindak, memiliki pikiran yang tajam'.

Dari penjelasan di atas, berdasarkan makna kanyouku atama ga kireru termasuk ke dalam 体、性格、態度を

\section{表す慣用句 “karada, seikaku, taido wo}

arawasu kanyouku', yaitu kanyouku yang menunjukkan tubuh, sifat dan tingkah laku. Dalam data (1) kanyouku atama ga kireru mendapat padanan 'cerdas' dalam BSa.

Pada data (1) kanyouku atama ga kireru ditunjukkan oleh tokoh Tsukuru yang menjelaskan sifat dan tingkah laku tokoh Aka yang 'cerdas'. Tsukuru sedang membandingkan kecerdasan Aka dan Haida. Tsukuru menganggap kecerdasan Aka lebih tertuju ke arah praktik atau tindakan, sedangkan kecerdasan Haida lebih murni dan teoritis. Dalam menjelaskan kecerdasan Aka, Tsukuru menggunakan kanyouku atama ga kireru yang mendapat padanan 'cerdas' dalam BSa pada data (1).

Strategi penerjemahan idiom yang digunakan pada data (1) adalah parafrasa. Parafrasa adalah mengungkapkan kembali kanyouku dengan cara lain tanpa mengubah maknanya. Salah satu bentuk strategi parafrasa adalah idiom diterjemahkan ke bentuk bukan idiom (Lestari, 2018:12). Penggunaan strategi parafrasa pada data (1) ditunjukkan oleh kanyouku atama ga kireru diterjemahkan menjadi "cerdas" dalam BSa. "Cerdas" berarti 'sempurna perkembangan akal dan budinya (untuk berpikir, mengerti dan sebagainya), tajam pikiran'. Cerdas bukan sebuah idiom. Oleh karena itu strategi penerjemahan idiom yang digunakan pada data (1) adalah parafrasa.

Prosedur penerjemahan idiom yang digunakan oleh penerjemah pada data (1) adalah transposisi, yaitu prosedur penerjemahan yang melibatkan pengubahan bentuk gramatikal dari $\mathrm{BSu}$ ke dalam BSa tanpa mengubah maknanya (Vinay \& Darbelnet (dalam Venuti, 2000:88)). Kanyouku pada data (1) mengalami transposisi unit. Salah satu contoh dari transposisi unit adalah adanya pergeseran leksikal frasa menjadi kata (Muliani, 2016:108). Hal ini dapat dilihat dari pergeseran frasa 'atama ga kireru' dari BSu ke dalam bentuk kata 'cerdas' dalam BSa, seperti berikut :

$$
\mathrm{BSu} \quad \mathrm{BSa}
$$

頭 が 切れる : erdas

$\begin{array}{ccc}\mathrm{N} & \mathrm{P} \quad \mathrm{V} & \mathrm{A} \\ & \text { Frasa Verba } & \text { Kata }\end{array}$

Dari penjelasan di atas dapat disimpulkan bahwa idiom verba atama ga kireru yang mendapat padanan "cerdas" dalam BSa pada data (1) diterjemahkan menggunakan strategi parafrasa dan prosedur transposisi unit. Jika atama ga kireru diterjemahkan secara leksikal atau kata per kata maka pembaca akan kesulitan memahami maksud dari kanyouku tersebut, penggunaan strategi serta prosedur penerjemahan yang tepat dapat membantu pembaca memahami maksud dari kanyouku dan bahasa yang disampaikan akan terasa lebih alami. Kanyouku atama ga kireru biasanya digunakan ketika menjelaskan sifat atau tingkah laku seseorang yang pandai dalam menangani sesuatu dengan cepat atau orang yang memiliki kemampuan berpikir dan bertindak dengan cepat.

\section{Data 16}

目と鼻の先

Me to hana no saki

Mata/P/Hidung/P/Ujung, di depan 
$\mathrm{TSu}$ : 「あなたがそう思うなら、も ちろんそれでいいけど」と沙 羅は言った。「でもせっかく 遠くまで行くんだから、他の 場所には寄らなくていいの？ タリンやサンクト。ペテルス ブルクも目と鼻の先だけど」

"Anata ga sou omou nara, mochiron sore de ii kedo" to Sara wa itta. "Demo sekkaku tooku made ikundakara, hoka no basho ni wa yoranakuteiino? Tarin ya Sankuto. Peterusuburuku mo me to hana no saki dakedo"

(Murakami, 2013:236)

TSa : "Kalau kamu tidak apa-apa begitu, tidak masalah juga, memang”, kata Sara. "Tapi pada kesempatan pergi sejauh ini kamu tidak mau singgah ke tempat lain? Tallinn atau Sankt-Peterburg juga ada di depan hidung".

(Ota, 2018:219)

Kanyouku me to hana no saki terbentuk dari gabungan antara nomina ditambah nomina, yaitu nomina 目 ' $m e$ ', partikel と'to', dan nomina 鼻の先 'hana no saki'. Berdasarkan struktur pembentuknya, data (16) kanyouku me to hana no saki termasuk ke dalam idiom nomina atau meishi kanyouku.

Nomina me berarti 'mata, daya lihat, penglihatan, pandangan' (Matsuura, 2005:617-618). Nomina hana berarti 'hidung' (Matsuura, 2005:247). Sedangkan nomina saki berarti 'ujung, di depan, di muka, dahulu, dulu' (Matsuura, 2005:839). Selanjutnya partikel to berarti 'dan, dengan' dan partikel no menunjukkan kepunyaan.

Makna leksikal dari kanyouku pada data (16) adalah 'di depan mata dan hidung'. Makna idiomatikal 'me to hana no saki menurut proverbencyclopedia.com adalah 'jarak yang dekat, sangat dekat'. Dalam Garrison (2006:33) me to hana no saki bermakna 'waktu yang akan datang, secepatnya, benar-benar di situ'. Dapat disimpulkan bahwa makna leksikal kanyouku me to hana no saki adalah 'sangat dekat atau akan datang secepatnya'.

Kanyouku me to hana no saki mengalami perluasan makna secara metafora. Hal ini dikarenakan adanya persamaan sifat antara makna leksikal dan makna idiomatikalnya. Letak mata dan hidung manusia pada wajah pasti berdekatan, maka untuk menggambarkan sesuatu yang sangat dekat digunakan kanyouku me to hana no saki. Dalam hal ini ranah sumber ditunjukkan oleh letak hidung dan mata yang berdekatan, sedangkan ranah sasarannya adalah kedekatan jarak atau hal yang akan datang.

Berdasarkan makna, kanyouku me to hana no saki termasuk dalam 状態、程 度、価値を表す慣用句 ‘joutai, teido, kachi wo arawasu kanyouku', yaitu kanyouku yang menunjukkan kondisi, tingkatan, nilai atau harga. Pada data (16) kanyouku to hana no saki mendapat padanan 'di depan hidung' dalam BSa.

Kondisi 'sudah sangat dekat' pada data (16) ditunjukkan oleh tokoh Sara yang menyarankan tokoh Tsukuru untuk berkunjung ke Tallin (ibu kota negara Estonia) atau ke Sankt-Peterburg di Rusia karena jaraknya yang dekat dengan kota tujuan Tsukuru, yaitu Helsinki di Finlandia. Mengingat Tsukuru sudah jauh-jauh datang dari Jepang ke Finlandia, Sara meminta Tsukuru untuk mempertimbangkan singgah ke tempat lain yang jaraknya lumayan dekat dari Helsinki. Kondisi 'sudah di depan hidung' atau 'sangat dekat' digambarkan dengan kanyouku me to hana no saki.

Strategi penerjemahan idiom yang digunakan oleh penerjemah pada data 
(16) adalah using an idiom of similar meaning and form 'menggunakan idiom dengan makna dan bentuk yang mirip atau hampir sama'.

Pada data (16) kanyouku me to hana no saki diterjemahkan ke dalam bentuk idiom yang bentuk dan maknanya mirip atau hampir sama dalam BSa. Di depan hidung dalam bahasa Indonesia merupakan sebuah idiom yang bermakna 'dekat sekali, hampir bersentuhan' (Chaer, 1993:57). Selain di depan hidung, idiom dalam bahasa Indonesia yang juga memiliki makna 'dekat sekali' dan berhubungan dengan anggota tubuh hidung adalah di muka hidung (Badudu, 2008:101). Kanyouku me to hana no saki dan idiom di depan hidung merupakan idiom yang terdiri dari item leksikal yang sama yaitu frasa nomina yang mengandung unsur anggota tubuh hidung serta memiliki makna yang sama. Oleh karena itu strategi penerjemahan idiom yang digunakan oleh penerjemah adalah menggunakan idiom dengan makna dan bentuk yang mirip atau hampir sama. Kecocokan seperti ini hanya bisa dicapai sesekali dalam penerjemahan idiom.

Prosedur penerjemahan idiom yang digunakan oleh penerjemah pada data (16) adalah terjemahan harfiah. Terjemahan harfiah ditunjukkan oleh penerjemah yang menerjemahkan setiap kata pembentuk kanyouku BSu berdasarkan makna leksikalnya, kemudian menyesuaikannya dengan kaidah BSa (Elfayanti, 2015). Makna leksikal kanyouku me to hana no saki adalah 'di depan hidung dan mata'. Penerjemah menerjemahkan kata pembentuk kanyouku me to hana no saki kemudian menyesuaikannya dengan kaidah dalam BSa, sehingga kanyouku me to hana no saki mendapat padanan 'di depan hidung' dalam Bsa. Hal ini menunjukkan bahwa penerjemah menerapkan prosedur terjemahan harfiah (literal translation) pada data (16).
Dari penjelasan di atas dapat disimpulkan bahwa idiom verba me to hana no saki yang mendapatkan padanan idiom yang sama dalam BSa yaitu 'di depan hidung' mengalami strategi penerjemahan using an idiom of similar meaning and form dan prosedur terjemahan harfiah. Pada data (16) kanyouku me to hana no saki bermakna kondisi 'jarak yang dekat, sangat dekat' sama dengan idiom di depan hidung dalam BSa.

\section{Data 25}

\section{口が重い}

Kuchi ga omoi

Mulut/P/Berat

$\mathrm{TSu}$ : どちらかといえばロが重く、 よく顔が赤くなり、社交が苦 手で、初対面の人と一緒にい ると落ちつかなかつた。

Dochira ka to ieba kuchi ga omoku, yoku kao ga akakunari, shakou ga nigate de, shoutaimen no hito to isshoni iru to ochitsukanakatta.

(Murakami, 2013:13)

TSa : Dia cenderung pendiam, mukanya mudah merah, kurang pandai bergaul, dan merasa tidak nyaman saat bersama orang yang baru pertama kali ditemui.

(Ota, 2018:11)

Pada data (25) bentuk kamus dari kanyouku ロが重く 'kuchi ga omoku' adalah ロが重い ‘kuchi ga omoi’. Kanyouku kuchi ga omoi terbentuk dari gabungan antara nomina dan adjektiva, yaitu nomina $\square$ ' $k u c h i$ ', partikel が ' $g a$ ' dan adjektiva 重い'omoi'. Berdasarkan struktur pembentuknya, data (25) kanyouku kuchi ga omoi termasuk ke 
dalam idiom adjektiva atau keiyoushi kanyouku.

Nomina kuchi berarti 'mulut, katakata, indera pengecap' (Matsuura, 2005:557-558). Sedangkan adjektiva omoi berarti 'berat' (Matsuura, 2005:762). Makna leksikal dari kanyouku kuchi ga omoi adalah 'mulutnya berat' atau 'berat mulut' dalam bahasa Indonesia. Makna idiomatikal kuchi ga omoi menurut proverb-encyclopedia.com adalah 'sedikit bicara, jarang bicara'.

Makna leksikal dan makna idiomatikal kanyouku kuchi wo hasamu berhubungan secara metonimi. Kuchi ga omoi memiliki makna leksikal 'berat mulut'. Mulut adalah tempat keluarnya suara atau perkataan. Saat mulut berat atau tidak dapat dibuka maka tidak dapat menghasilkan suara, perkataan atau ucapan. Oleh sebab itu orang yang sedikit bicara atau pendiam disebut berat mulut. Dari penjelasan tersebut dapat disimpulkan bahwa makna leksikal dan idiomatikal kanyouku kuchi ga omoi mengalami perluasan makna secara metonimi sebab-akibat.

Berdasarkan maknanya, kanyouku

kuchi ga omoi termasuk dalam 体, 性格、 態度を表す慣用句 ‘karada，seikaku， taido wo arawasu kanyouku', yaitu kanyouku yang menunjukkan tubuh, sifat dan tingkah laku. Hal ini disebabkan oleh makna kanyouku kuchi ga omoi 'pendiam, tidak banyak bicara' yang merupakan sifat atau tingkah laku.

Pada data (25) kanyouku kuchi ga omoi mendapat padanan 'pendiam' dalam BSa. Kanyouku kuchi ga omoi ditunjukkan oleh narasi penulis tentang sifat atau tingkah laku tokoh Tsukuru. Tsukuru saat SMA digambarkan sebagai seorang lelaki muda berwajah lumayan tampan. Menurut Tsukuru sendiri, ia bukanlah orang yang memiliki hobi atau bakat. Tsukuru menggambarkan dirinya sendiri sebagai orang yang pendiam, kurang pandai bergaul dan mukanya mudah memerah. Sifat 'pendiam' pada data (25) digambarkan dengan penggunaan kanyouku kuchi ga omoi.

Strategi penerjemahan idiom yang digunakan oleh penerjemah pada data (25) adalah parafrasa. Pada data (25) kanyouku kuchi ga omoi mendapat padanan "pendiam" dalam BSa. Pendiam memiliki makna 'tidak banyak bicara', dan pendiam bukanlah sebuah idiom dalam BSa. Dalam menerjemahkan kanyouku kuchi ga omoi penerjemah mengungkapkan kembali makna dari kuchi ga omoi ke dalam bentuk tuturan lain dalam BSa tanpa mengubah maknanya yaitu menggunakan strategi parafrasa.

Prosedur penerjemahan idiom yang digunakan oleh penerjemah pada data (25) adalah transposisi atau pergeseran bentuk. Kanyouku kuchi ga omoi merupakan frasa adjektiva yang mengalami perubahan bentuk menjadi kata sifat atau adjektiva "pendiam" dalam Bsa, sehingga prosedur penerjemahan idiom yang digunakan oleh penerjemah pada data (25) adalah transposisi unit, seperti berikut :

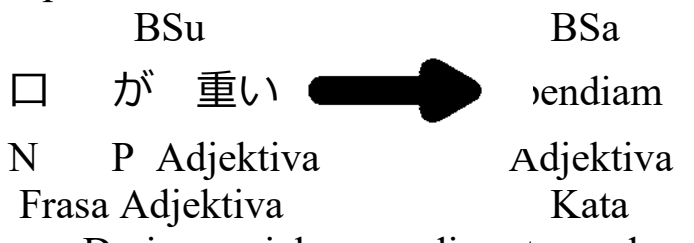

Dari penjelasan di atas dapat disimpulkan bahwa idiom adjektiva $k u c h i$ ga omoi yang mendapat padanan "pendiam" dalam BSa pada data (25) mengalami strategi penerjemahan parafrasa dan prosedur transposisi unit.

Kanyouku kuchi ga omoi merupakan kanyouku yang mewakili sifat atau tingkah laku, yaitu pendiam. Makna pendiam tidak selalu berkesan negatif, terkadang kanyouku kuchi ga omoi memiliki kesan positif tergantung konteks kalimat. Dalam contoh pada data (25) kanyouku kuchi ga omoi memiliki makna negatif karena tokoh Tsukuru menganggap sifatnya yang pendiam 
adalah sebuah kelemahan dibandingkan teman-temannya yang lain.

\section{SIMPULAN}

Berdasarkan hasil analisis data yang telah dilakukan, diketahui bahwa dalam novel SMTTKJT (2013) karya Haruki Murakami terdapat 35 kanyouku anggota tubuh bagian atas. Berdasarkan struktur pembentuknya, kanyouku pada novel ini terdiri atas 31 doushi kanyouku, 3 keiyoushi kanyouku dan 1 meishi kanyouku.

Berdasarkan maknanya, kanyouku dalam novel ini terdiri atas 4 kanyouku yang mewakili perasaan, 5 kanyouku yang menyatakan sifat atau tingkah laku, 20 kanyouku yang menunjukkan tindakan dan 6 kanyouku yang menyatakan kondisi.

Dalam penelitian ini, strategi using an idiom of similar meaning and form merupakan langkah awal dari prosedur terjemahan harfiah. Hal ini menunjukkan ada beberapa kanyouku dalam bahasa Jepang yang bentuk dan maknanya hampir sama dengan idiom dalam bahasa Indonesia. Strategi parafrasa merupakan langkah awal dari strategi terjemahan harfiah, kesepadanan dan transposisi. Prosedur yang cenderung digunakan penerjemah adalah transposisi unit yaitu mengubah frasa kanyouku dari $\mathrm{BSu}$ menjadi bentuk kata dalam BSa.

Penelitian ini berfokus pada penerjemahan idiom dalam novel dan menggunakan teori semantik kognitif. Peneliti selanjutnya dapat meneliti mengenai penerjemahan idiom dalam komik, anime, drama atau karya sastra lainnya dan lebih mengembangkan penelitian mengenai penerjemahan idiom ditinjau dari segi budaya, sosiolinguistik dan pragmatik.

\section{DAFTAR PUSTAKA}

Andriani, N., Artana, I. N. R., \& Aryani, M. R. D. (2019). Metode Dan Ideologi Penerjemahan Makna Kanyouku Organ Tubuh Dalam
Cerpen Kappa Karya Akutagawa Ryuunosuke. Jurnal Sakura : Sastra, Bahasa, Kebudayaan dan Pranata Jepang, 1(2), 92-103.

Badudu, J.S. (2008). Kamus Ungkapan Bahasa Indonesia. Jakarta: PT. Kompas Media Nusantara.

Baker, M. (1992). In other words: A course book on translation. London: Routledge.

Chaer, A. (1993). Kamus Idiom Bahasa Indonesia. Flores : Nusa Indah.

Dadi, N. W., Wedayanti, N. P. L., \& Budiana, I. M. (2018). Strategi Penerjemahan dan Pergeseran Makna Istilah Budaya Sosial dalam Terjemahan Komik Garudayana Saga Volume 1-4 Karya Is Yuniarto. Jurnal Humanis, 22(4), 986-993.

Elfayanti, L. G. W. (2015). Strategi dan Prosedur Penerjemahan Idiom Bahasa Jepang dalam Komik Doraemon Teema Betsu Kessaki Sen Edisi 1-17. Jurnal Humanis, 11(3), 1-7.

Garrison, J. G. (2006). Idiom Bahasa Jepang: Memakai Nama-Nama Bagian Tubuh. Terjemahan oleh Nasir Ramli. Jakarta: Kesaint Blanc.

Hoed, B. H. (2006). Penerjemahan dan Kebudayaan. Jakarta: Pustaka Jaya.

Lestari, P., Widiati, S. W., \& Isnaini, Z. L. (2018). Penerjemahan Idiom dalam Komik Hayate no Gotoku Volume 36. JOM FKIP UNRI, 5(1), 1-15. 
Machali, R. (2000). Pedoman Bagi Penerjemah. Grasindo: Jakarta.

Matsuura, K. (2005). Kamus JepangIndonesia. Jakarta : Gramedia Pustaka Utama.

Miharu, A. (2002). Yoku Wakaru Goi. Tokyo: ALC.

Muliani, P. A. (2016). Pergeseran Penerjemahan Idiom Pada Novel Oda Nobunaga Karya Sohachi Yamaoka. Jurnal Humanis, 14(1), 104-111.

Muneo, I. (1992). Reikai Kanyouku Jiten. Tokyo: Sootakusha.

Murakami, H. (2013). Shikisai wo Motanai Tazaki Tsukuru to Kare no Junrei no Toshi. Tokyo: Bungeishunju.

Murakami, H. (2018). Tsukuru Tazaki Tanpa Warna dan Tahun Ziarahnya. Terjemahan oleh Ribeka Ota. Jakarta : Kepustakaan Populer Gramedia.

Nida, E. A., \& Taber, C. R. (1982). The Theory And Practice Of Translation. New York: United Bible Societies.

Septiyani, E. (2018). Makna Idiomatikal Hiyuteki Kanyouku Pada Komik [飲食店完全バイブル] Karya Akira Harada Dkk Volume 12. Hikari, 6(2), 1-12.

Sudaryanto. (2015). Metode dan Aneka Teknik Analisis Bahasa : Pengantar Penelitian Wahana Kebudayaan Secara Linguistis. Yogyakarta : Sanata Dharma University Press.
Sutedi, D. (2011). Dasar-dasar Linguistik Bahasa Jepang. Bandung: Humaniora.

Venuti, L. (2000). The Translation Studies Reader. London: Routledge.

Widiyani, A. (2016). Makna Kanyouku yang Berkaitan Dengan Bagian Tubuh Hana (Hidung), Kuchi (Mulut), Mimi (Telinga), Me (Mata), Dan Shita (Lidah). Jurnal SORA, 1(1), 25-38.

Encyclopedia of proverbs and idioms. (2021). Diakses pada 8 Juni 2021, dari : $\quad$ https://proverbencyclopedia.com. 